\title{
Control of Postnatal Apoptosis in the Neocortex by RhoA-Subfamily GTPases Determines Neuronal Density
}

\author{
Hitomi Sanno, ${ }^{1,2}$ Xiao Shen, ${ }^{1,2}$ Nilgün Kuru, ${ }^{3,4}$ Ingo Bormuth, ${ }^{5,6}$ Kristin Bobsin, ${ }^{1,2}$ Humphrey A. R. Gardner, ${ }^{7}$ \\ Dorde Komljenovic, ${ }^{2}$ Victor Tarabykin, ${ }^{5,6}$ Reha S. Erzurumlu, ${ }^{4}$ and Kerry L. Tucker ${ }^{1,2}$ \\ ${ }^{1}$ Interdisciplinary Center for Neurosciences and ${ }^{2}$ Institute of Anatomy, University of Heidelberg, D-69120 Heidelberg, Germany, ${ }^{3}$ Department of Biology, \\ Faculty of Education, Cumhuriyet University, TR-58140 Sivas, Turkey, ${ }^{4}$ Department of Anatomy and Neurobiology, University of Maryland School of \\ Medicine, Baltimore, Maryland 21201, ${ }^{5}$ Max Planck Institute for Experimental Medicine, D-37075 Göttingen, Germany, ${ }^{6}$ Institute of Cell Biology and \\ Neurobiology, Charité-Universitätsmedizin Berlin, Campus Mitte, D-10098 Berlin, Germany, and 7Novartis Institutes for BioMedical Research, Cambridge, \\ Massachusetts 02139
}

Apoptosis of neurons in the maturing neocortex has been recorded in a wide variety of mammals, but very little is known about its effects on cortical differentiation. Recent research has implicated the RhoA GTPase subfamily in the control of apoptosis in the developing nervous system and in other tissue types. Rho GTPases are important components of the signaling pathways linking extracellular signals to the cytoskeleton. To investigate the role of the RhoA GTPase subfamily in neocortical apoptosis and differentiation, we have engineered a mouse line in which a dominant-negative RhoA mutant (N19-RhoA) is expressed from the Mapt locus, such that all neurons of the developing nervous system are expressing the N19-RhoA inhibitor. Postnatal expression of N19-RhoA led to no major changes in neocortical anatomy. Six layers of the neocortex developed and barrels (whisker-related neural modules) formed in layer IV. However, the density and absolute number of neurons in the somatosensory cortex increased by $12-26 \%$ compared with wild-type littermates. This was not explained by a change in the migration of neurons during the formation of cortical layers but rather by a large decrease in the amount of neuronal apoptosis at postnatal day 5, the developmental maximum of cortical apoptosis. In addition, overexpression of RhoA in cortical neurons was seen to cause high levels of apoptosis. These results demonstrate that RhoA-subfamily members play a major role in developmental apoptosis in postnatal neocortex of the mouse but that decreased apoptosis does not alter cortical cytoarchitecture and patterning.

\section{Introduction}

Programmed neuronal cell death plays a central role in the dynamic organization of developing neuronal networks (Purves, 1990). The classical neurotrophic model describes populations of peripheral neurons that compete for limiting amounts of survival factors (e.g., NGF, BDNF, and neurotrophins 3 and 4/5) (Bibel and Barde, 2000). Failure to bind neurotrophins results in an apoptotic response and neuronal death. The activation of apoptotic ma-

\footnotetext{
Received July 12, 2009; revised Jan. 25, 2010; accepted Jan. 30, 2010

This work was supported by the German Research Foundation [Deutsche Forschungsgemeinschaft: Sonderforschungsbereich 488, Teilprojekt B7/B9 (K.L.T.) and Exzellenzcluster 257 (V.T.)], the University of Heidelberg [Excellence Cluster Cellular Networks (K.L.T.)], National Institutes of Health/National Institute of Neurological Disorders and Stroke Grant NS039050 (R.S.E.), the Max Planck Society (V.T.), and the Heisenberg Program (V.T.). We thank Joachim Kirsch for generous scientific support, Karin Gorgas for enormous help with anatomical analysis, Yves-Alain Barde for thoughtful commentary on this manuscript, Silvia Arber for the floxed stop and Mapt targeting constructs, FrankZimmermann for blastocyst injections, Stefan Offermanns for Ella::CRE mice and rhotekin-expressing bacteria, Julia Hoffmann for preparation of the rhotekin beads, Robert Grosse for Rac1 and cdc42 expression plasmids, Antonio Caputi for the anti-parvalbumin antibody, Ulrich Müller for the N19-RhoA cDNA, Günter Giese and Annemarie Scherbarth for assistance with confocal microscopy, and Dmitry Rusanov and Jana Hechler for superb technical assistance.

Correspondence should be addressed to Dr. Kerry L. Tucker, Institute of Anatomy, University of Heidelberg, Im Neuenheimer Feld 307, 69120 Heidelberg, Germany. E-mail: Kerry.Tucker@urz.uni-hd.de.

H. Sanno's present address: Department of Physiology and Center for Integrative Genomics, University of Lausanne, CH-1015 Lausanne, Switzerland.

D. Komljenovic's present address: Department of Medical Physics, German Cancer Research Center, INF 280, D-69120 Heidelberg, Germany.

DOI:10.1523/JNEUROSCI.3318-09.2010

Copyright $\odot 2010$ the authors $\quad 0270-6474 / 10 / 304221-11 \$ 15.00 / 0$
}

chinery in the periphery is well investigated, but corresponding mechanisms in developing brain are poorly understood. Apoptosis plays a crucial role in embryonic development of the cerebral cortex, cerebellum, and brainstem. The key apoptosis proteins caspase-3, caspase-9, Apaf1, Bax, Bcl- $\mathrm{X}_{\mathrm{L}}$, and survivin have been demonstrated to regulate and execute apoptosis through mouse knock-out studies (for review, see Kuan et al., 2000). However, the proximal causes of apoptosis within the embryonic brain remain unknown.

Neuronal loss is known to occur in postnatal mammalian neocortex (Heumann et al., 1978; Finlay and Slattery, 1983; Heumann and Leuba, 1983; Price and Blakemore, 1985), marked by a wave of apoptosis that peaks at postnatal day 5 (P5) to P7 in rodents (Pearlman, 1985; Ferrer et al., 1990, 1992; Spreafico et al., 1995; Verney et al., 2000). Aside from IGF-1 (Chrysis et al., 2001; Hodge et al., 2007), the molecular players in postnatal cortical apoptosis are not known.

The Rho GTPases RhoA, RhoB, and RhoC belong to and define the RhoA-subfamily within the Ras superfamily of small GTP-binding proteins (Hall, 1998). They cycle between a GDPbound, inactive and a GTP-bound, active state. These two states are primarily regulated by the guanine nucleotide exchange factors (GEFs) and the GTPase-activating proteins families (EtienneManneville and Hall, 2002), which promote the activation and inactivation, respectively, of GDP- and GTP-bound Rho. One of the most important targets of active RhoA is Rho-associated ki- 
nase (ROCK), a serine/threonine kinase with multiple substrates (Katoh et al., 1998). Although much is known about the modeling of axons and dendrites by Rho GTPases (Luo, 2000), the role that they play in the control of apoptosis is controversial. In vitro studies have indicated that Rho can induce apoptosis in hippocampal (Donovan et al., 1997) and cortical (Zhang et al., 2007) neurons. In vivo studies have delivered conflicting evidence, with one investigation showing that apoptosis of spinal cord motor neurons increased during inhibition of Rho activity (Kobayashi et al., 2004), whereas a rat model of spinal cord injury showed that Rho inhibition reduced injury-related apoptotic levels (Dubreuil et al., 2003).

To investigate Rho GTPases in the control of postnatal cortical apoptosis, we developed a mouse line in which a dominant-negative inhibitor of Rho GTPases is expressed specifically in neurons. We found that inhibition of Rho GTPases in postnatal cortical neurons in vivo resulted in a significant reduction in apoptosis of excitatory neurons and a corresponding increase in the absolute number and density of neurons in the cortex. Despite the increase in neuronal numbers, cortical lamination and pattern formation were unaltered. These findings suggest that postnatal apoptosis does not contribute to cytoarchitectonic differentiation and cellular patterning of the neocortex.

\section{Materials and Methods}

Generation of the N19-RhoA mouse line. All animal experiments were in compliance with the regulations of Baden-Württemberg. To construct the targeting vector, a human RhoA cDNA containing the N19 mutation and an $\mathrm{N}$-terminal hemagglutinin (HA) tag was inserted into a vector (pLSL; courtesy of Dr. Silvia Arber, University of Basel, Basel, Switzerland) downstream of a transcriptional stop cassette flanked by loxP sites. The resultant cassette was inserted into a targeting vector (courtesy of Dr. Silvia Arber) (Hippenmeyer et al., 2005) containing genomic Mapt sequence and a neomycin-selectable marker. The linearized targeting vector was electroporated into J1 embryonic stem (ES) cells as described previously (Tucker et al., 2001), and 28 neomycinresistant colonies were analyzed by Southern blot, using external genomic probes as described (Tucker et al., 2001).

Targeted, euploid ES cells were injected into C57BL/6 blastocysts. Two high-contribution male chimeras derived from two different ES cell lines were bred with C57BL/6 wild-type mice to generate two independent N19-RhoA mouse lines. Germ-line transmission of the targeted Mapt allele was confirmed by Southern blots of mouse tail DNA. Subsequent generations were maintained on a C57BL/6 background. For genotyping the N19-RhoA mice, the primers 5'-TACGACGTGCCCGACTAC-3' and 5'-GCTGTGTCCCACAAAGCC-3' delivered a 220 bp amplicon. EIIa::CRE mice were genotyped using the primers $5^{\prime}$-GCCGAAATTGCCAGGATCAG-3' and 5' -AGCCACCAGCTTGCATGATC-3', giving a 486 bp amplicon. For the Southern blot analysis of the efficiency of the
A
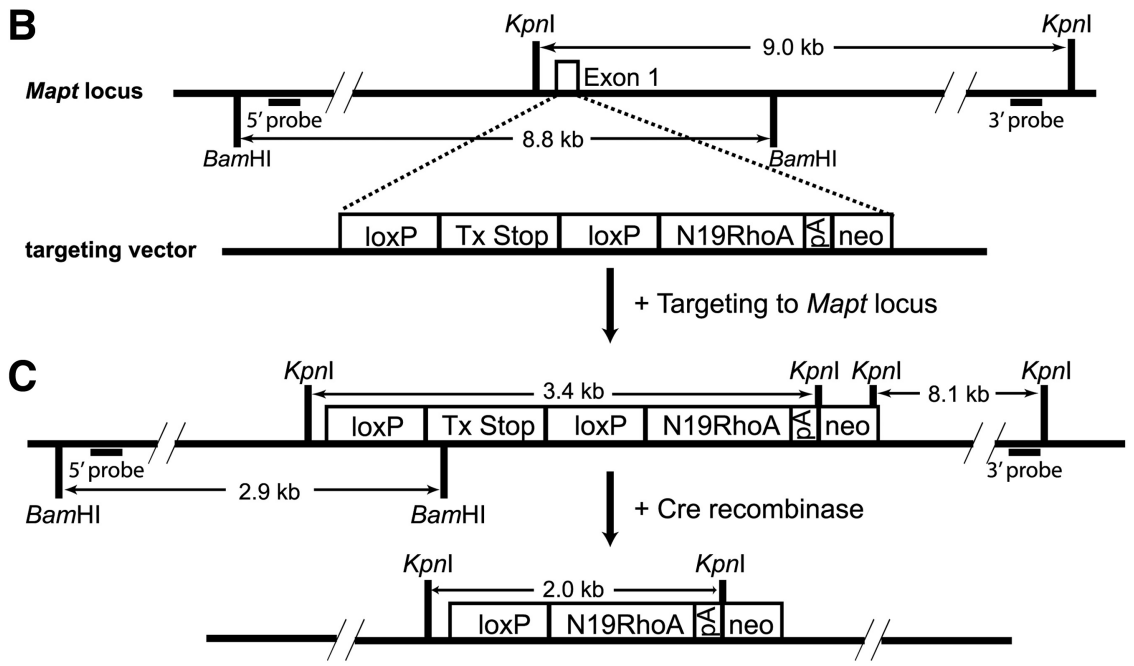

D
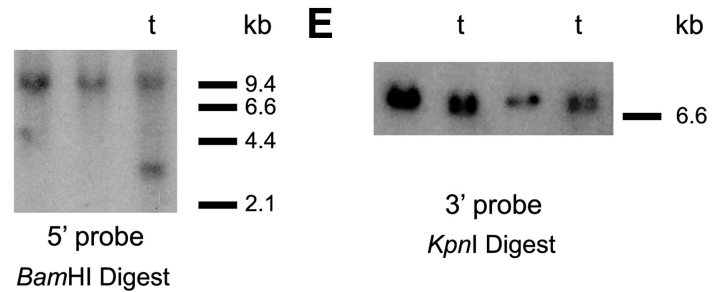

3' probe

Kpnl Digest

Figure 1. Inducible expression of dominant-negative RhoA (N19-RhoA) at the Mapt locus. $\boldsymbol{A}-\boldsymbol{C}$, Schematic indicating targeting and expression schemes: loxP, loxP sites; Tx Stop, transcriptional stop sequence; N19RhoA, HA-tagged N19-RhoA cDNA; pA, Pgk1 polyadenylation sequence; neo, G418-resistance cassette. Scheme is not to scale. $\boldsymbol{A}$, Scheme indicating Cre-mediated inducor Kpnl digestion, followed by Southern blotting with 5' or 3' external probes, respectively. C, Map of targeted Mapt allele, (bottom) Cre-mediated recombination. Genomic alterations caused by the knock-in construct are detected eliminates the floxed transcriptional stop sequence, as revealed by Kpnl digestion and Southern blotting with a RhoA probe. D, $\boldsymbol{E}$ Southern blot of ES cell clones using the $5^{\prime}(\boldsymbol{D})$ and $3^{\prime}(\boldsymbol{E})$ external probes. Targeted clones (t) show a wild-type band and a band corresponding to the targeted allele at $2.9 \mathrm{~kb}(\boldsymbol{D})$ and $8.1 \mathrm{~kb}(\boldsymbol{E})$. DNA markers are indicated (right) with size in kilobase pairs.

Cre-based excision of the stop cassette, a 600 bp N19-RhoA cDNA fragment was used as a probe.

Rhotekin beads. Rhotekin-expressing bacteria (Ren et al., 1999) were cultured in $20 \mathrm{ml}$ of Luria broth (LB) media with ampicillin $(100 \mu \mathrm{g} / \mathrm{ml})$ and chloramphenicol $(34 \mu \mathrm{g} / \mathrm{ml})$ on a shaker at $37^{\circ} \mathrm{C}$ overnight. The following day, 2-4 $\mathrm{ml}$ of overnight culture were added to $4 \times 500 \mathrm{ml} \mathrm{LB}$ media with ampicillin and chloramphenicol on a shaker at $37^{\circ} \mathrm{C}$ and induced with $500 \mu \mathrm{l}$ of $0.5 \mathrm{M}$ isopropyl- $\beta$-D-thiogalactopyranoside until the $\mathrm{OD}_{600}$ became between 0.7 and 0.8 , followed by $3 \mathrm{~h}$ incubation at $30^{\circ} \mathrm{C}$ on a shaker. The bacterial cultures were placed in $500 \mathrm{ml}$ tubes and centrifuged for $10 \mathrm{~min}$ at $4000 \mathrm{rpm}$, and the pellets were washed twice with $200 \mathrm{ml}$ of cold $1 \times$ PBS. The pellets were resuspended and centrifuged for $10 \mathrm{~min}$ at $4000 \mathrm{rpm}$ at $4^{\circ} \mathrm{C}$. These pellets were resuspended in $4 \times 50 \mathrm{ml}$ lysis buffer, the cells were sonicated for $15 \mathrm{~s}$ six times at $130 \mathrm{~W}$, and $500 \mu \mathrm{l}$ of $10 \%$ Triton $\mathrm{X}-100$ was added per tube to make the final concentration of $0.1 \%$ Triton X-100 and incubated for 15 min on ice, rocking. Lysates were decanted in eight ultracentrifuge tubes on ice and 

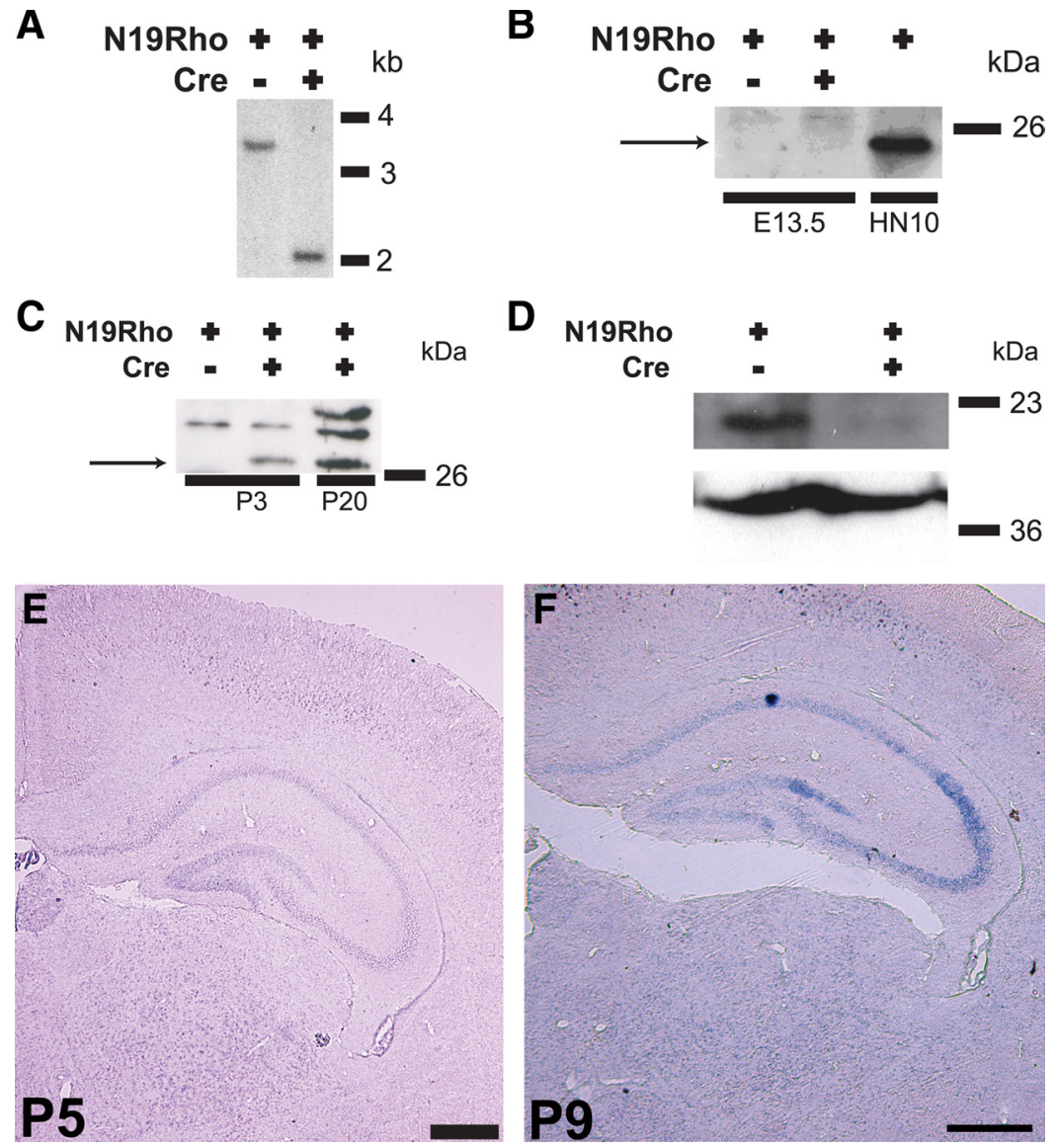

Figure 2. Postnatal expression of N19-RhoA inhibits endogenous Rho activity. A, Complete recombination of the targeted Mapt allele during in vivo exposure to Ella::Cre recombinase was detected in acute cultures of cerebellar granule neurons, indicated by Southern blots on Kpnl-digested genomic DNA with a RhoA cDNA probe. Band sizes are explained in Figure 1 C. DNA markers are indicated (right) with size in kilobase pairs. B, C, Western blot analysis indicates HA-tagged N19-RhoA expression (arrow) in the brain of E13.5 (B) and newborn $(\boldsymbol{C})$ animals after exposure to Cre recombinase, using an anti-HA antibody. $\boldsymbol{B}$, HN10, Positive control in which HA-tagged N19-RhoA expression construct was transfected into HN10 cells. D, N19-RhoA acts as a dominant-negative inhibitor of RhoA function in vivo. Brain lysates from N19-RhoA or control mice were lysed, incubated with Sepharose beads coupled to the Rho-binding domain of Rhotekin, and protein bound to Rho-binding domain subsequently analyzed by Western blotting, using an anti-RhoA antibody to detect wild-type RhoA (22 kDa). Loading levels were analyzed using an anti-actin antibody (42 kDa). $\boldsymbol{B}-\boldsymbol{D}$, Protein markers (in kilodaltons) are indicated (right). $\boldsymbol{E}, \boldsymbol{F}$, In situ hybridization analysis of N19-RhoA expression in the telencephalon of P5 $(\boldsymbol{E})$ and P9 $(\boldsymbol{F})$ N19-RhoA mice. Dorsal is to the top. Scale bars: $200 \mu \mathrm{m}$.

centrifuged for $12 \mathrm{~min}$ at 27,000 rpm (Hitachi HimacCS 100fx). The beads $(1.3 \mathrm{ml})$ (Glutathione Sepharose 4B; GE Healthcare) for $2 \mathrm{~L}$ of medium was washed in a $50 \mathrm{ml}$ tube twice with $15 \mathrm{ml}$ of $1 \times \mathrm{PBS}$ at $4^{\circ} \mathrm{C}$. Beads were centrifuged at $1000 \mathrm{rpm}$ at $2^{\circ} \mathrm{C}$ for $1 \mathrm{~min}$. Rhotekin lysates were added to the beads and incubated for $45 \mathrm{~min}$, shaking horizontally to avoid making bubbles. The beads were washed with $20 \mathrm{ml}$ of cold wash buffer [50 mм Tris-HCl, pH 7.5, 0.5\% Triton X-100, $150 \mathrm{~mm} \mathrm{NaCl,} 5 \mathrm{~mm}$ $\mathrm{MgCl}_{2}, 10 \mu \mathrm{g} / \mathrm{ml}$ aprotinin (Roche), $10 \mu \mathrm{g} / \mathrm{ml}$ leupeptin (Roche), and 10 $\mu \mathrm{g} / \mathrm{ml}$ PMSF] for $1 \mathrm{~min}$ at $1000 \mathrm{rpm}$ at $2^{\circ} \mathrm{C}$, and then the supernatant was removed. Beads were resolved in $20 \mathrm{ml}$ of wash buffer $/ 10 \%$ glycerol, and aliquoted beads were kept at $-80^{\circ} \mathrm{C}$.

Rhotekin pulldown assay. Cerebral cortex from postnatal animals was carefully microdissected and flash frozen in liquid nitrogen. Tissue was lysed (50 mм Tris- $\mathrm{HCl}, \mathrm{pH} 7.4,150 \mathrm{~mm} \mathrm{NaCl}$, and $5 \mathrm{~mm} \mathrm{MgCl}_{2}$ ) with 10 $\mu \mathrm{g} / \mathrm{ml}$ aprotinin (Roche), $10 \mu \mathrm{g} / \mathrm{ml}$ leupeptin (Roche), and $10 \mu \mathrm{g} / \mathrm{ml}$ PMSF (Carl Roth $\mathrm{GmbH}$ ) by sonication three times for $15 \mathrm{~s}$. Brain lysate $(450 \mu \mathrm{g})$ was incubated with $200 \mu \mathrm{l}$ Rhotekin beads for $19 \mathrm{~h}$ at $4^{\circ} \mathrm{C}$. Lysates were centrifuged at $4^{\circ} \mathrm{C}$ for $15 \mathrm{~min}$ at $2900 \mathrm{rpm}$, and the pellet was resuspended and washed three times in $50 \mathrm{~mm}$ Tris- $\mathrm{HCl}, \mathrm{pH} 7.5,0.5 \%$ Triton X-100, $150 \mathrm{~mm} \mathrm{NaCl}, 5 \mathrm{~mm} \mathrm{MgCl}_{2}, 10 \mu \mathrm{g} / \mathrm{ml}$ aprotinin, $10 \mu \mathrm{g} / \mathrm{ml}$ leupeptin, and $10 \mu \mathrm{g} / \mathrm{ml}$ PMSF for 5 min with rotation. The pellet was resuspended in $15 \mu \mathrm{l}$ of sample buffer and electrophoresed in acrylamide gels, and RhoA levels were analyzed by Western blot. The antibodies (Abs) used included mouse anti-RhoA (sc-418, 1:500; Santa Cruz Biotechnology) and rabbit anti-actin (A2066, 1:1000; Sigma-Aldrich).

Western blotting. Western blotting was performed on homogenized brain as described previously (Willaredt et al., 2008), with either a mouse anti-RhoA Ab (sc-418, 1:1000; Santa Cruz Biotechnology) or a rabbit anti-HA $\mathrm{Ab}$ (sc-805, 1:1000; Santa Cruz Biotechnology). For a positive control, HN10 cells were transiently transfected with the HA-tagged N19RhoA construct used above, and protein lysates were prepared $48 \mathrm{~h}$ after transfection.

In situ hybridization. In situ hybridization on paraffin sections was performed (Shakèd et al., 2008) with a human RhoA cDNA (Deutsches Ressourcenzentrum für Genomforschung $\mathrm{GmbH}$ ).

Barrel cortex analyses. Four P9 and four P65 mice (two control and two transgenic each age) were used to analyze the barrel cortex. In these experiments, serial sections through flattened cortices and coronal brain sections were processed with routine histological methods for visualization of barrel patterns. The brains were split in half along the sagittal plane. The left cortex from each half was removed and flattened between two glass slides. Thirty-micrometer-thick coronal and tangential sections were kept in PBS, pH 7.4. Alternate sections were stained for either Nissl, cytochrome oxidase (CO) histochemistry or serotonin transporter (5-HTT) immunohistochemistry for P9 brains. For CO histochemistry, free-floating sections were incubated with phosphate buffer containing $0.5 \mathrm{mg} / \mathrm{ml}$ cytochrome C (type III; Sigma), $0.5 \mathrm{mg} / \mathrm{ml}$ diaminobenzidine (DAB) (Sigma), and $40 \mathrm{mg} / \mathrm{ml}$ sucrose for $2-4 \mathrm{~h}$ at $37^{\circ} \mathrm{C}$ in a shaker incubator. Alternate sections were stained with $2 \%$ cresyl violet for Nissl staining. For 5-HTT immunohistochemistry, sections were treated as below (immunohistochemical analysis) for peroxidase detection using an anti-5-HTT rabbit polyclonal Ab (1:10,000; Diasorin). Sections were mounted on slides, dehydrated, cleared in xylene, and coverslipped with Permount.

Immunohistochemical analysis and cell counting. Free-floating $20 \mu \mathrm{m}$ brain sections were rinsed in $2 \% \mathrm{H}_{2} \mathrm{O}_{2}$ in $10 \%$ methanol for 20 min to block endogenous peroxidase activity, and biotinylated secondary antibody and peroxidase-labeled avidin-biotin complex were applied according to the instructions of the manufacturer (Vectastain Elite ABC; Vector Laboratories). Sections were washed in PBS for $30 \mathrm{~min}$, developed in $0.05 \% \mathrm{DAB}$ (Sigma) with the addition of $0.006 \% \mathrm{H}_{2} \mathrm{O}_{2}$, washed in PBS for $10 \mathrm{~min}$, and mounted (Aquatex medium). The following primary antibodies were used, with clone name, source, and dilution indicated: mouse anti-neuronal-specific nuclear protein (NeuN) (MAB377, 1:1000; Millipore Corporation), mouse anti-parvalbumin (clone PARV19, 1:2000; Sigma), rabbit anti-calretinin (catalog \#7699/4, 1:3000; Swant), mouse anti-calbindin (catalog \#300, 1:3000; Swant), rabbit anticleaved-caspase-3 (clone 5A1, 1:200; Cell Signaling Technology), rabbit anti-phospho-histone H3 (Ser10, rabbit 06-570, 1:200; Millipore Corporation), and rabbit anti-ER81 (1:200; kind gift from Dr. Silvia Arber). For caspase-3, phospho-histone H3, and ER81 stains, secondary Abs were used as described previously (Brachmann et al., 2007).

Sections were photographed with a Leica DMLB microscope equipped with a Leica DFC320 CCD camera and two different air objectives: a 40X 
HCX PLAN APO objective (numerical aperture, 0.85) and a $5 \times$ HC PL FLUOTAR objective (numerical aperture, 0.15 ), using the program Firecam 3.1 (Leica). Somatosensory cortex and the anterior extent of the visual cortex was used for analyses. Ten slides were chosen at equidistant locations within this area, photographed on both the right and left sides, and subsequently quantitated. In NeuN-stained preparations, the darkly stained nuclei were easy to identify at both magnifications. In the photos taken with a $5 \times$ objective, the entire width of the cortex could be identified, nuclei in specific layers were counted by hand, and these data are presented in Figure 4. Photographs taken at $40 \times$ were assigned to specific layers, and a correction for the thickness of the section and the size of the nuclei was made according to Abercrombie (1946). Because the size of the nuclei did not vary significantly between wild-type (layer IV, $10.0 \pm$ $0.9 \mu \mathrm{m}$; layer V, $11.8 \pm 1.0 \mu \mathrm{m}$; layer VI, $10.8 \pm 0.8 \mu \mathrm{m}$; mean $\pm \mathrm{SEM}$; $n>150$ for all layers) and N19-RhoA (layer IV, $10.2 \pm 0.9 \mu \mathrm{m}$; layer V, $12.8 \pm 0.9 \mu \mathrm{m}$; layer VI, $10.8 \pm 0.7 \mu \mathrm{m}$; mean \pm SEM; $n>150$ for all layers) mice, this correction did not affect the relative increase in neuron number when comparing wild-type with N19-RhoA mice, and the results agreed with the counts made using sections photographed with the $5 \times$ objective. With the $40 \times$ objective, we recorded an increase in layer IV of $23.4 \pm 1.9 \%$, in layer $\mathrm{V}$ of $18.0 \pm 2.7 \%$, and in layer $\mathrm{VI}$ of $21.0 \pm 5.8 \%$ ( $n=4$; mean \pm SEM, Student's $t$ test). All counting was performed in a blind manner.

Developmental analysis of cortical layer formation. Brains from newborn (P1) or P3 N19-RhoA and control littermate pups were perfused transcardially and removed for processing to paraffin blocks. For paraffin sectioning, tissue was dehydrated in an ascending ethanol row, isopropanol, and xylene. Brains from N19-RhoA and control littermates were embedded in one common paraffin block and were sectioned at $10 \mu \mathrm{m}$ on a Leica sliding microtome. Sections were deparaffinated using xylene and isopropanol and were rehydrated in a descending ethanol row. Antigen unmasking was performed by boiling for $10 \mathrm{~min}$ in either citric buffer ( $\mathrm{pH} \mathrm{6)}$ or Tris EDTA ( $\mathrm{pH} 9$ ) in a microwave oven at $600 \mathrm{~W}$. Sections were washed with Tris buffer containing $2 \%$ milk powder (Tris+), blocked in 20\% goat serum in PBS for $1 \mathrm{~h}$, and incubated with primary antibodies in 5\% goat serum in PBS for $4 \mathrm{~h}$. Sections were washed three times with Tris + , incubated for 20 min with appropriate biotinylated secondary antibodies (Vector Laboratories), washed three times with Tris + , incubated for $10 \mathrm{~min}$ with streptavidin/biotin complex (Vector Laboratories), washed three times in Tris (without milk powder), incubated for 10 min with DAB substrate (Vector Laboratories), washed, and counterstained with hematoxylin. Sections were dehydrated in an ascending ethanol row, followed by isopropanol and xylene. Coverslips were applied using Eukitt. Primary antibodies were directed against Reelin (mouse IgG, 1:500; Calbiochem), Satb2 (mouse IgG, 1:1000; from V. Tarabykin), Ctip2 (rat IgG, 1:500; Abcam), Brn2 (polyclonal goat, 1:200; Santa Cruz Biotechnology), Tbr2 (polyclonal rabbit, 1:500; Abcam), and Pax6 (polyclonal rabbit, 1:500; Millipore Bioscience Research Reagents).

In vitro apoptosis assays. Five to seven embryonic day 16.5 (E16.5) embryos were removed from timed pregnant CD-1 mice, the cerebral hemispheres cut apart with a scalpel, the meninges were peeled away, and $\sim 3 \mathrm{~mm}$ of the cortex lying above the hippocampus was cut out and digested in $0.25 \%$ trypsin (Invitrogen) at $37^{\circ} \mathrm{C}$ for $15 \mathrm{~min}$. After three washes in HBSS/10 mM HEPES, pH 7.3, cells were triturated with a firepolished Pasteur pipette, and 700,000 cells were centrifuged $7 \mathrm{~min}$ at $100 \times g$ and electroporated in $100 \mu \mathrm{l}$ nucleofection solution (mouse neuron nucleofector kit, Program O5; Amaxa Biosystems), containing either $5 \mu \mathrm{g}$ of an expression vector expressing enhanced green fluorescent protein (pEGFP-N1), a RhoA expression vector [wild-type human RhoA cDNA with a 5 '-localized HA tag cloned into the EcoRI/ NotI site of the pcDNA3.1(+) vector], or myc-tagged wild-type human Rac1 or cdc42 expression plasmids (kind gift from Dr. Robert Grosse, Philipps University of Marburg, Marburg, Germany). Transfected cells were plated in 24-well plates at a concentration of 30,000 cells per $13 \mathrm{~mm}$ coverslip (pretreated with $1 \mathrm{mg} / \mathrm{ml}$ poly-L-lysine and $1 \mu \mathrm{g} / \mathrm{ml} \mathrm{laminin}$ ) in MEF medium (DMEM/10\% fetal calf serum $/ 2 \mathrm{mM}$ glutamine), incubated at $37^{\circ} \mathrm{C} / 5 \% \mathrm{CO}_{2}$, with an exchange of MEF medium to Neurobasal medium/1× B27 supplement/2 mM glutamine (Invitrogen) after $24 \mathrm{~h}$,
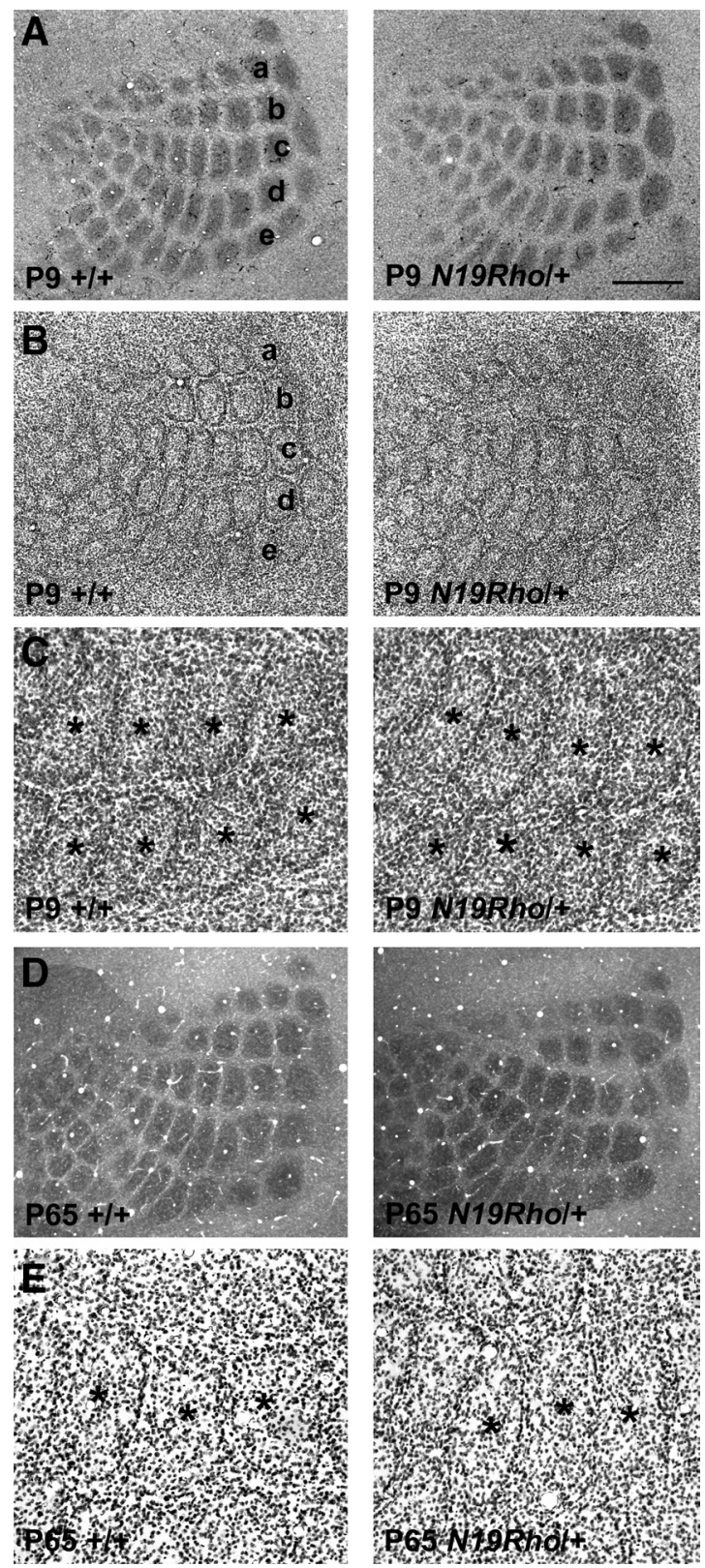

Figure 3. Normal barrel patterns in $\mathrm{N} 19-\mathrm{RhoA}$ mice. $A, B, A t \mathrm{P} 9$, thalamocortical afferent terminal patterns, as assessed with 5-HTT immunohistochemistry $(\boldsymbol{A})$, are similar between the control and N19-RhoA mice as are the barrels as cytoarchitectonic entities, revealed by Nissl stain $(\boldsymbol{B})$. Whisker-related barrel rows $(\boldsymbol{a}-\boldsymbol{e})$ are indicated. $\boldsymbol{C}$, High-magnification views of Nissl-stained barrels in rows $\boldsymbol{d}$ and $\boldsymbol{e}$. Asterisks mark barrel centers. $\boldsymbol{D}$, Cytochrome oxidase staining in P65 mice also shows clear barrel patterns in both the control and N19-RhoA mice. These micrographs were montaged from serial sections. $\boldsymbol{E}$, High-magnification views of Nissstained barrels in $\mathrm{P} 65$ mice also revealed clear barrels. Barrel centers are marked with asterisks. Scale bars: $\boldsymbol{A}, \boldsymbol{B}, 500 \mu \mathrm{m} ; \boldsymbol{C}, \boldsymbol{E}, 200 \mu \mathrm{m} ; \boldsymbol{D}, 700 \mu \mathrm{m}$.

and fixed after $48 \mathrm{~h}$ in culture for $10 \mathrm{~min}$ with $4 \%$ paraformaldehyde, $\mathrm{pH}$ 7.4 , at room temperature. Immunocytofluorescence was performed as described previously (Shakèd et al., 2008), with the following changes: cells were permeabilized for 5 min with $0.2 \%$ Triton X-100 only at the beginning of the staining, followed by a quenching of the cells for $5 \mathrm{~min}$ with $0.1 \%$ sodium borohydride. The following primary antibodies were used: FITC-coupled goat anti-GFP (G8965×12A, 1:2000; US Biologicals), mouse anti-HA tag (clone 6E2, 1:200; Cell Signaling Technology), mouse anti-c-Myc tag (clone 9E10, sc-40, 1:100; Santa Cruz Biotechnology), rabbit anti-cleaved-caspase-3 (Asp175, clone 5A1, 1:200; Cell Signaling Technology). Secondary Abs were used as described previously (Brach- 

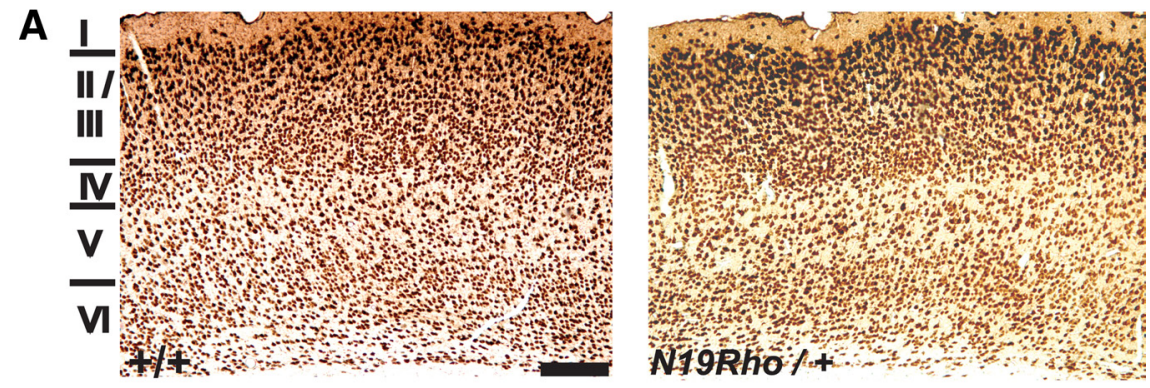

B

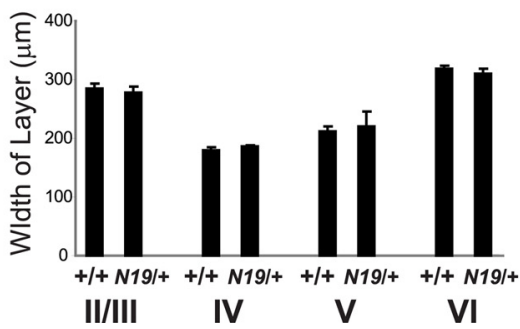

C

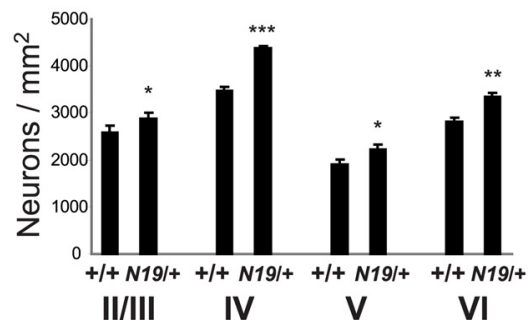

Figure 4. N19-RhoA mice show an increased density of neurons in somatosensory cortex. $A$, Immunohistochemical staining of somatosensory cortex in $\mathrm{P} 65$ wild-type $(+/+)$ and $\mathrm{N} 19-\mathrm{RhoA} /+$ mice, using an antibody recognizing NeuN. For each coronal section, dorsal is to the top, and lateral is to the right. Layers I-VI are indicated to the left. $\boldsymbol{B}$, Quantification of the dorsoventral width of layers II/III, IV, V, and VI. C, Quantification of NeuN-positive neurons in layers II/III, IV, V, and VI. * $p<0.5,{ }^{* *} p<0.01$, ${ }^{* * *} p<0.001$, Student's $t$ test $(n=4)$. Scale bar: $A, 200 \mu \mathrm{m}$.

mann et al., 2007). $4^{\prime}, 6^{\prime}$-Diamidino-2-phenylindole (DAPI) $(2 \mu \mathrm{g} / \mathrm{ml})$ was used to stain nuclei. The stained cortical neurons were analyzed with epifluorescent microscopy (Microscope BX61WI; Olympus) using identical exposure conditions and a digital CCD camera (F-View II; Soft Imaging $\mathrm{GmbH}$ ) in combination with imaging software (analysis, Soft Imaging $\mathrm{GmbH}$ ). One hundred cells positive for either pEGFP-N1 or Rho-HA were assayed for their cellular and nuclear morphology and for cleaved caspase-3 activity. Statistical analysis was performed using the Mann-Whitney $U$ test.

\section{Results}

A mouse line expressing a dominant-negative inhibitor of Rho specifically in newborn neurons of the nervous system To inhibit the activity of proteins in the RhoA GTPase subfamily, we used the N19-RhoA construct, a dominant-negative inhibitor in which the threonine at position 19 has been mutated to asparagine (N) (Qiu et al., 1995). N19-RhoA is predicted to block the GTPase activity of endogenous RhoA-subfamily GTPases through competitive binding to GEFs (Feig, 1994), and it has been suggested that this substitution also disturbs Rho GTPase activity by interfering with an essential $\mathrm{Mg}^{2+}$ ion required for guanine nucleotide binding in all Ras superfamily GTP-binding proteins (Farnsworth and Feig, 1991). It has been shown to specifically inhibit members of the RhoA-subfamily GTPases and to demonstrate no direct effect on other Rho GTPase family members, such as cdc42 or Rac, either biochemically (Ren et al., 1999) or in cell-based assays (Hall, 1998; WojciakStothard et al., 1999; Bouzahzah et al., 2001). However, it cannot be definitively excluded that N19-RhoA may also affect cdc42 or Racbased pathways by binding to promiscuous GEFs that interact with both RhoA- and cdc42/Rac-subfamily members (Rossman et al., 2005). To distinguish the mutant RhoA protein from the endogenous murine RhoA, a human N19-RhoA cDNA was modified to express an $\mathrm{HA}$ tag at its $\mathrm{N}$ terminus.

The N19-RhoA cDNA was engineered to allow for its inducible expression after exposure to the Cre recombinase. A cassette was constructed in which the N19-RhoA cDNA lies downstream of a transcriptional stop cassette flanked by two loxP sites (Fig.
$1 B)$. This entire cassette was placed into the first exon of the gene (Mapt) encoding tau, which had been used previously to express EGFP specifically in newborn neurons (Tucker et al., 2001). We chose an inducible approach because we were concerned that the long-term expression of N19-RhoA in all neurons of the mouse could cause potentially lethal side effects if N19- RhoA were constitutively expressed from the Mapt locus. Because of the floxed stop cassette, transcription from the endogenous tau promoter at the altered locus should produce a truncated, non-proteincoding transcript, and the introduced cDNA should not be transcribed (Fig. $1 A)$. Exposure to the Cre recombinase should cause recombination between the two loxP sites, excision of the stop cassette, and subsequent expression of the N19-RhoA protein (Fig. 1A). The targeting vector was electroporated into J1 ES cells, and 49 G418-resistant colonies were picked, of which 28 were analyzed by Southern blot. Using $5^{\prime}$ (Fig. $1 B, D$ ) and $3^{\prime}$ (Fig. $1 B, E$ ) external probes, five clones were found to be targeted using both probes, indicating a targeting efficiency of $18 \%$. Two independent euploid clones were used to generate chimeras, both of which transmitted the targeted allele through the germ line. With respect to all data presented in this paper, similar phenotypes were observed for both lines.

\section{Inducible expression of N19-RhoA in postnatal brain}

To remove the floxed stop cassette from the Mapt locus, the N19RhoA mice were crossed with the EIIa::Cre mouse line, which expresses Cre recombinase under the control of the adenovirus EIIa promoter (Lakso et al., 1996). In this line, Cre recombinase is expressed already in the zygote, and all cells of the resulting embryo should show recombination at the loxP sites and removal of the floxed stop cassette. After Cre-based recombination, the N19-RhoA cassette can then be expressed specifically in neurons. Compound heterozygotes for both the N19-RhoA and the EIIa::Cre alleles $\left(\mathrm{Cre}^{+} / \mathrm{N} 19-\mathrm{RhoA}^{+}\right)$were generated, and cultures of cerebellar granule neurons (CGNs) were prepared from P5 $\mathrm{Cre}^{-} / \mathrm{N} 19-\mathrm{RhoA}^{+}$and $\mathrm{Cre}^{+} / \mathrm{N} 19-\mathrm{RhoA}^{+}$mice. The ability of the loxP sites to undergo recombination by Cre recombinase was examined using Southern blot analysis. KpnI-digested genomic DNA from CGN cultures was probed with a human RhoA cDNA. The cassette before recombination was seen to be $3.4 \mathrm{~kb}$ in the $\mathrm{Cre}^{-} / \mathrm{N} 19-\mathrm{RhoA}^{+}$cultures (Fig. 1D, 2A). Cre-mediated recombination would remove the $1.4 \mathrm{~kb}$ floxed transcriptional stop sequence, with a corresponding decrease in the size of the RhoAhybridizing band on Southern blotting (Fig. 1D). Indeed, in the $\mathrm{Cre}^{+} / \mathrm{N} 19-\mathrm{RhoA}^{+}$cultures, no signal could be detected at 3.4 $\mathrm{kb}$, whereas a strong band was seen at $2.0 \mathrm{~kb}$, indicating a $100 \%$ efficiency in the removal of the floxed stop cassette in CGN during exposure to Cre recombinase (Fig. 2A). Protein lysates were prepared from embryonic and postnatal brain of $\mathrm{Cre}^{+} / \mathrm{N} 19-$ $\mathrm{RhoA}^{+}$mice to examine expression of the N19-RhoA construct and were examined with Western blot analysis using an antibody recognizing the HA-tagged N19-RhoA. Surprisingly, no embryonic expression could be detected (Fig. $2 B$ ), despite the fact that 
EGFP is very strongly expressed from the tau locus as early as 9.5 d postcoitum (Tucker et al., 2001). Expression could first be detected at P3 in the brain, with expression continuing at P20 (Fig. 2C). The expression of the N19-RhoA protein was shown to act as an inhibitor of endogenous Rho function by performing a Rhotekin assay on lysates from the cerebral cortex of N19-RhoAexpressing or control mice. A large reduction in active GTPbound Rho was observed (Fig. 2D). To examine the distribution of RhoA expression, in situ hybridization was performed on brain sections from postnatal N19-RhoA transgenic mice. At P5 and P9, expression could be seen throughout the neocortex and hippocampus, with particularly high levels in layers IV/V of the cortex and the pyramidal layers of CA1, CA3, and the dentate gyrus of the hippocampus (Fig. 2E,F).

\section{Cortical anatomy is not disrupted in N19-RhoA transgenic mice}

We examined the barrel cortex of P9 and P65 N19-RhoA transgenic mice to determine whether laminar differentiation and whisker-related barrel formation were affected. Six laminae of the parietal cortex were visible with Nissl (Fig. $3 B, C, E$ ) stains in transgenic mice, and there were no noticeable differences from the controls at both ages. CO histochemistry, a routine method for visualization of whisker-related patterns (i.e., cortical barrels) also revealed distinct patterning in the transgenic mice at both ages (Fig. 3D). In addition, we examined thalamocortical patterning with 5-HTT immunohistochemistry in P9 mice. Monoamine transporters are transiently expressed in the primary sensory thalamic nuclei in mice (Lebrand et al., 1998), and 5-HTT immunohistochemistry has been established as a reliable marker for thalamocortical afferent terminal patterns in the barrel cortex (Iwasato et al., 2000; Rebsam et al., 2002). The thalamocortical afferent patterning in the barrel cortex was similar between the N19-RhoA transgenic and control mice, in both the tangential and coronal planes (Fig. 3A).

The absolute number and density of neurons is increased in the somatosensory cortex in N19-RhoA transgenic mice

To assess the number of neurons within the barrel cortex, an antibody recognizing NeuN, which is expressed by all cortical neurons except for Cajal-Retzius cells (Mullen et al., 1992; Lyck et al., 2007), was used. Careful counting of the neurons in specific layers revealed a large and significant increase in the density of NeuN-positive neurons in layers II/III, IV, V, and VI of the somatosensory cortex of the N19-RhoA transgenic mice when counted at maturity (P65) such that, in layer II/III, neuronal density increased by $11.6 \pm 1.3 \%$, in layer IV by $26.4 \pm 1.9 \%$, in layer V by $17.2 \pm 1.5 \%$, and in layer VI by $18.7 \pm 1.2 \%(n=4$; mean \pm SEM, Student's $t$ test) (Fig. $4 A, C$ ). A similar increase was also observed in juvenile mice at P24 (supplemental Fig. 1A, available at www.jneurosci.org as supplemental material), indicating that the increase in neuronal number is already established at an early age. Because the dorsoventral width of the layers did not change significantly in the N19-RhoA transgenic mice (Fig. $4 B$ ), it can be concluded that the absolute number of neurons had increased by $12-26 \%$ in these cortical layers.

\section{The density of interneuron populations is not affected in} somatosensory cortex of N19-RhoA mice

$\mathrm{NeuN}$ is expressed by both excitatory projection neurons, which constitute the vast majority of the neurons in the cortex, and inhibitory interneurons, which make up $20-30 \%$ of the neuronal population (Markram et al., 2004). To distinguish which popu-
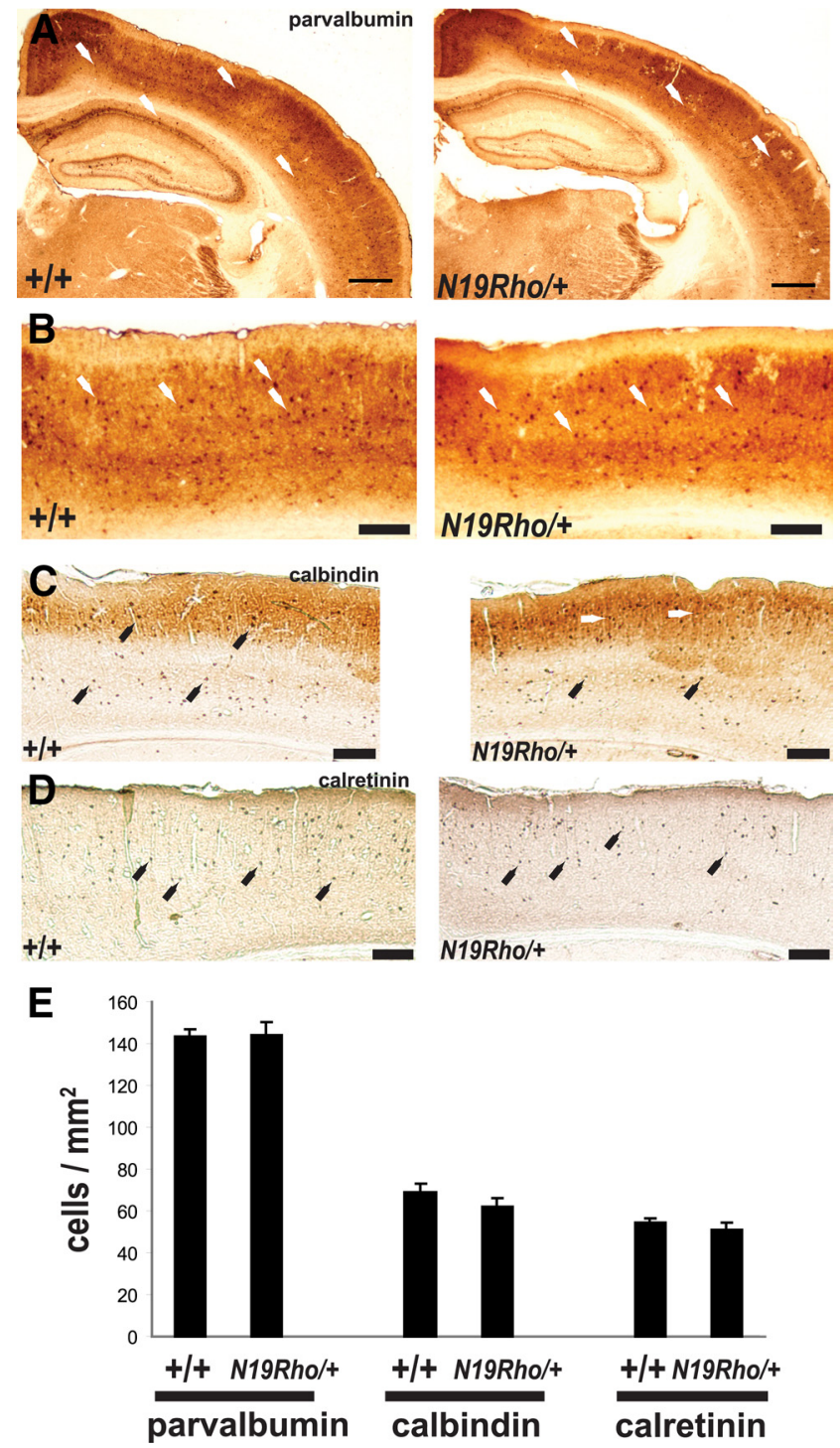

Figure 5. The density of interneurons is not affected in somatosensory cortex of N19-RhoA mice. $\boldsymbol{A}, \boldsymbol{B}$, Immunohistochemical staining of somatosensory cortex in $\mathrm{P} 65$ wild-type $(+/+)$ and $\mathrm{N} 19-\mathrm{RhoA} /+$ mice, using antibodies recognizing parvalbumin $(\boldsymbol{A}, \boldsymbol{B})$, calbindin $(\boldsymbol{C})$, and calretinin $(\boldsymbol{D})$. For each coronal section, one telencephalic half is shown, with dorsal to the top and lateral to the right. Arrows (white) indicate positive neurons. $\boldsymbol{B}$, Magnification of $\boldsymbol{A}$. $\boldsymbol{E}$, Quantification of interneurons. Scale bars: $\boldsymbol{A}, 500 \mu \mathrm{m} ; \boldsymbol{B}-\boldsymbol{D}, 200 \mu \mathrm{m}$.

lation was demonstrating an increase in the number in the cortex of the N19-RhoA mice, we performed stainings for interneuron subpopulations characterized by the expression of parvalbumin (Fig. 5A, $B$ ), calbindin (Fig. 5C), and calretinin (Fig. 5D). In all three cases, quantification of positive neurons revealed no difference in number between wild-type and N19-RhoA cortex (Fig. $5 E$ ). Because these interneurons do not show any change in number in the N19-RhoA cortex, we conclude that the change in neuronal density in the N19-RhoA cortex is attributable to an increase in the number of excitatory projection neurons and not in that of the interneuron population.

Neuronal migration and cell type specification of cortical neurons is not affected in N19-RhoA mice

RhoA activity has been implicated in the control of radial migration of cortical neurons (Hand et al., 2005), and it has been shown to be involved in a large number of migratory processes through- 


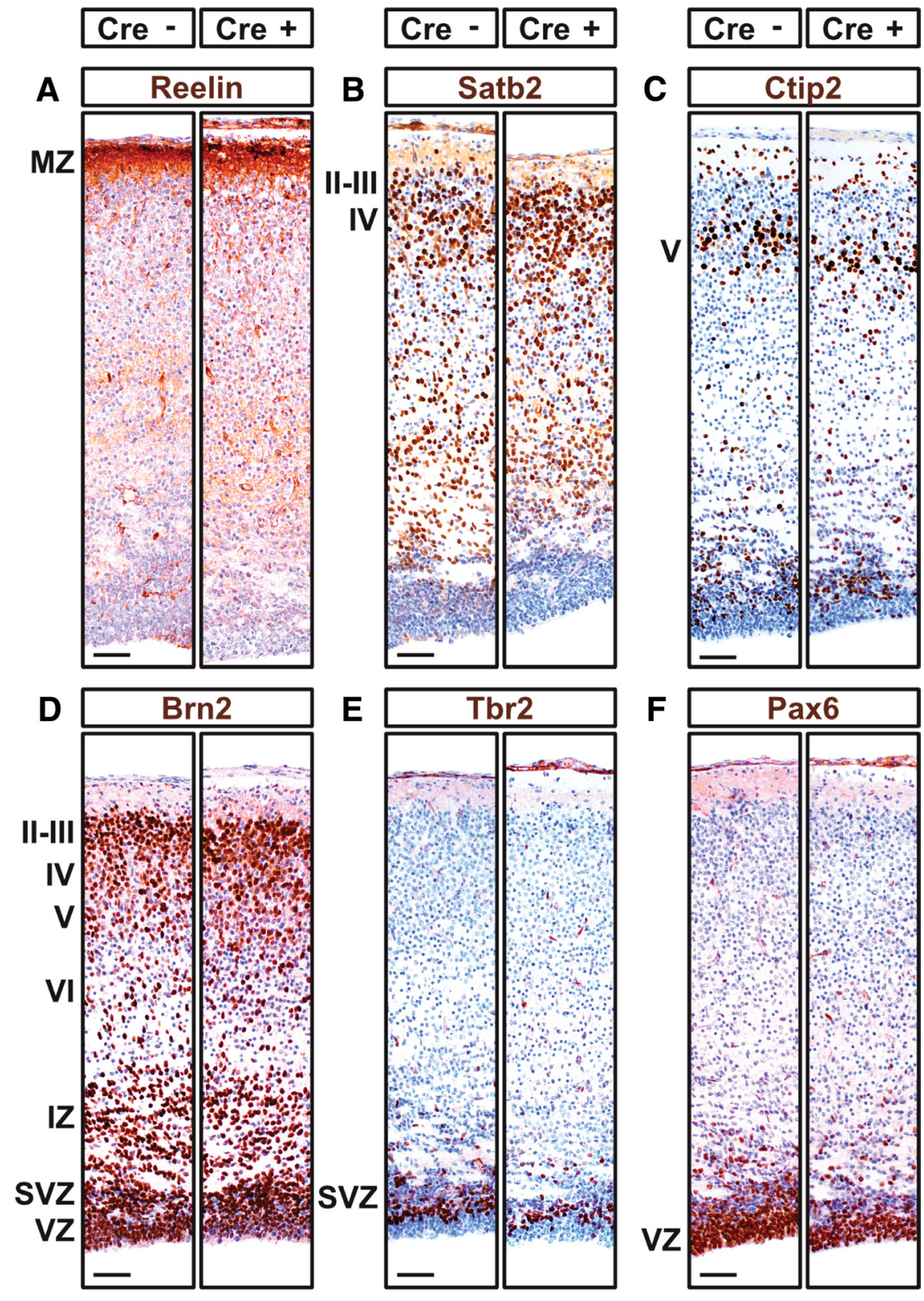

Figure 6. Migration and specification of cortical neurons is not affected in N19-RhoA mice. Characterization of radial migration and specification in coronal sections of somatosensory cortex from newborn (P1, day of birth) N19-RhoA-transgene-positive mice with or without Ella::Cre recombinase. $\boldsymbol{A}-\boldsymbol{F}$, Immunohistochemistry using primary antibodies raised against the characteristic layer-specific proteins: $\boldsymbol{A}$, Reelin; $\boldsymbol{B}$, Satb2; $\boldsymbol{C}$, Ctip2; $\boldsymbol{D}, \mathbf{B r n 2} ; \boldsymbol{E}$, Tbr2; $\boldsymbol{F}$, Pax6. For each coronal section, dorsal is to the top and lateral is to the right. II, III, IV, V, VI, Layers II-VI, respectively; MZ, IZ, VZ, SVZ, marginal, intermediate, ventricular, and subventricular zones, respectively. Scale bars, $50 \mu \mathrm{m}$.

out the developing nervous system (Liu and Jessell, 1998; Rupp and Kulesa, 2007; Carmona-Fontaine et al., 2008; Groysman et al., 2008). To investigate the possibility that the increased number of neurons in deeper cortex layers of N19-RhoA mice results from abnormal radial migration of upper layer neurons, we performed immunohistochemistry for typical layer-specific proteins in brain sections of newborn (P1) (Fig. 6) and P3 mice. We found the expression patterns of Reelin, Satb2, Ctip2, Brn2, Tbr2, and Pax6 (Fig. 6A-F) to be unchanged in N19-RhoA mice. In addition, in E16.5 cbs/cbs mutants, the number of mitotic cells at the cortical ventricular zone was not significantly altered in the cortex $(n=4 ; p=0.69$, Student's $t$ test) (supplemental Fig. $1 B$, available at www.jneurosci.org as supplemental material). Finally, we examined the expression of the layer V-specific transcription factor ER81 at P24 in juvenile mice, when layer formation is complete. Comparison of the distribution of ER81-positive neurons between wildtype and $\mathrm{N} 19-\mathrm{RhoA} /+$ cortex revealed that, in both cases, expression of ER81 was restricted to layer $\mathrm{V}$ (supplemental Fig. $1 C, D$, available at www.jneurosci.org as supplemental material), which confirmed that migration of cortical neurons is normal. Together, these results demonstrate that the specification and migration of cortical neurons was normal in the N19RhoA-expressing mice.

\section{Apoptosis is severely reduced in somatosensory cortex of N19-RhoA mice}

To test whether reduced apoptosis plays a role in the increase of neurons in cortical layers IV-VI of the N19-RhoA transgenic mice, the numbers of apoptotic cells were examined at P5. Postnatal days 5-8 have been reported to be the developmental peak of apoptosis in both the mouse and rat cortex (Pearlman, 1985; Ferrer et al., 1990, 1992; Spreafico et al., 1995; Verney et al., 2000). Apoptotic cells were detected using an antibody recognizing cleaved, activated caspase- 3 , a processed protein that is not only produced early during the apoptotic process but is also responsible for executing the proteolytic cascade common to both intrinsic and extrinsic apoptotic pathways (Porter and Jänicke, 1999) (Fig. $7 A-C)$. A dramatic reduction of $67.5 \%$ was observed in the cortex of the N19-RhoA transgenic mice at this time point (wildtype cortex, $94.7 \pm 6.4$ caspase-3-positive cells per section; N19-RhoA/+ cortex, $28.0 \pm 4.7$ caspase-3-positive cells per section; $n=4 ; p<0.001$, Student's $t$ test). Caspase-3-positive cells in both wild-type and N19-RhoA transgenic mice showed layer-appropriate morphology of neurons from upper (Fig. 7B) and lower (Fig. 7C) layers, and morphological analysis indicated that $>90 \%$ of the caspase-3-positive cells were neurons $(n=314)$ (Fig. 7C).

Because inhibition of Rho activity resulted in a decrease in the levels of apoptosis in vivo in postnatal cortex, we tested whether apoptosis could be promoted by the overexpression of wild-type RhoA in cortical neurons. Acutely isolated E16.5 cortical neurons were electroporated with expression constructs expressing either EGFP alone or HA-tagged wild-type RhoA and cultivated on poly-lysine-coated coverslips. RhoA-expressing neurons demonstrated high levels of apoptosis $48 \mathrm{~h}$ after transfection, as assayed by either expression of activated caspase-3 (Fig. $7 D-G$ ) or the presence of pyknotic nuclei (Fig. $7 D-G$ ). Indeed, the levels of apoptosis seen in both the control (EGFP-expressing) and RhoAexpressing neurons (Fig. $7 G$ ) were very similar to those reported for cortical cultures prepared from wild-type mice and mice 
lacking the antiapoptotic protein $\mathrm{Bcl}-\mathrm{X}_{\mathrm{L}}$ (Shindler et al., 1997). To test whether other members of the Rho GTPase subfamily could also induce apoptosis, constructs expressing myc-tagged wild-type Rac1 or cdc42 cDNAs were transfected into acutely isolated E16.5 cortical neurons. In distinct contrast to RhoA, neither of these constructs showed any influence on apoptotic levels (Fig. $7 H$ ).

\section{Discussion}

In this paper, we demonstrate that the RhoA-subfamily signaling pathway regulates the postnatal apoptosis of cortical neurons. Inhibition of Rho activity in vivo greatly reduced the amount of apoptosis occurring in postnatal cortex and resulted in a concomitant increase in the density and absolute number of neurons in the adult cortex. Overexpression of wild-type RhoA in vitro led to the apoptosis of cortical neurons, but this was not the case for other members of the Rho GTPase family, such as cdc42 or Racl. A significant increase in neuronal numbers in the somatosensory cortex did not interfere with lamination or barrel formation in layer IV. In layer IV of the rodent somatosensory cortex, thalamocortical afferent terminals from the ventroposteromedial thalamic nucleus form distinct patches reflecting the distribution of whiskers on the contralateral snout, and cortical neurons organize around these patches forming barrels (Woolsey and Van der Loos, 1970; Rebsam et al., 2002). The mechanisms underlying the formation of cell-dense barrel walls and cell-sparse barrel hollows in the cytoarchitectonic organization in the mouse somatosensory cortex are not clear. At the time of arrival and terminal arborization of thalamocortical axons, the developing layer IV is uniformly populated with neurons. Thalamocortical afferents are the first elements to show whisker-specific patterning, followed by layer IV neuronal patterning (Erzurumlu and Jhaveri, 1990; Senft and Woolsey, 1991). A potential mechanism contributing to barrel formation could be apoptotic events in postnatal barrel cortex. Our results, however, indicate that a significant reduction in layer IV neuronal apoptosis, caused by an inhibition of Rho activity, and a concomitant increase in neuronal numbers do not interfere with barrel formation. Barrel patterning most likely involves active distribution of layer IV neuronal somata and dendritic arbors with respect to thalamocortical axon arbor patches.

Apoptosis has been demonstrated to be a critical process during embryonic development in which to control the neuronal populations in both the CNS and PNS. This is the first report to show that Rho signaling is important for the survival of neurons
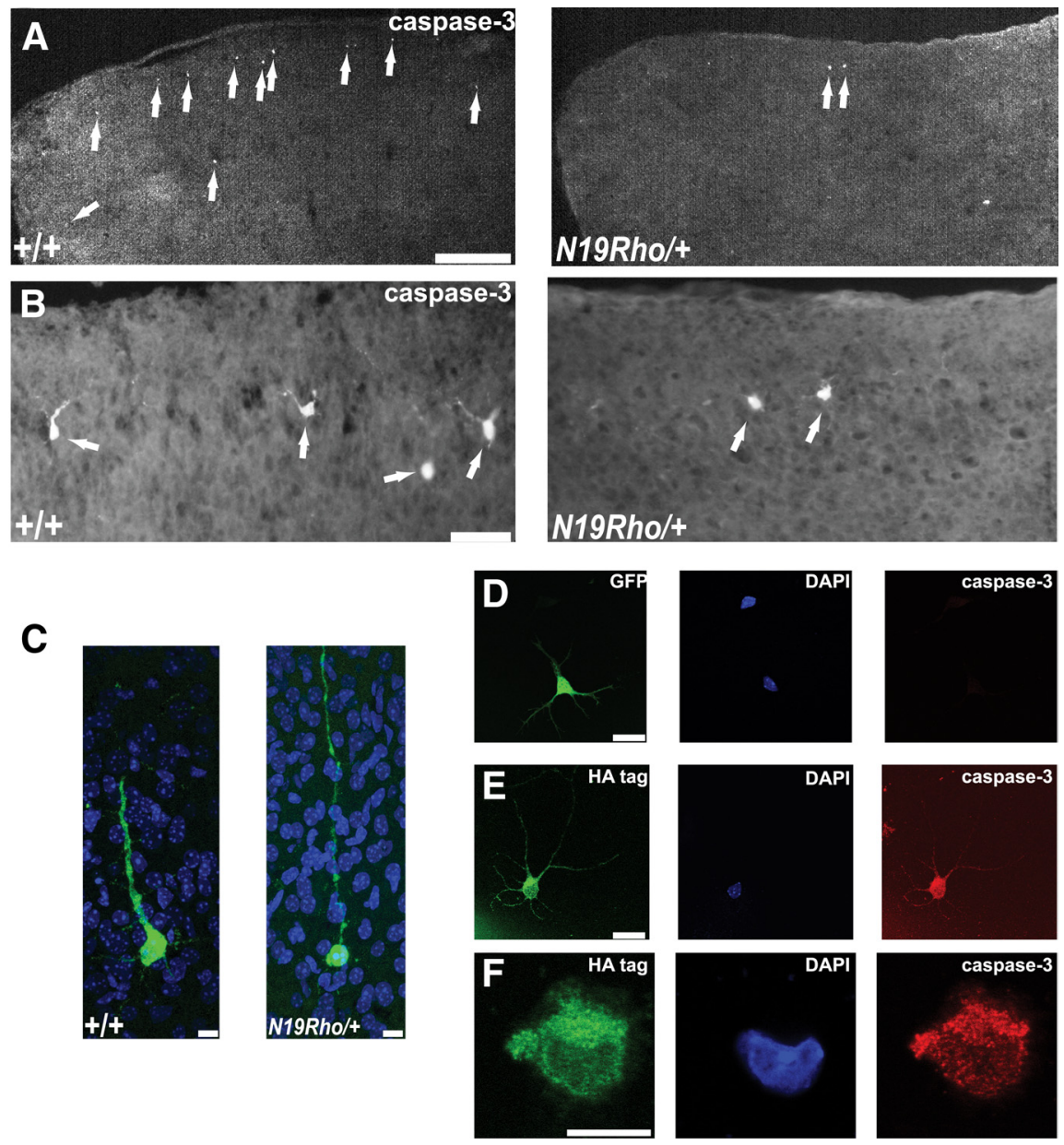

G

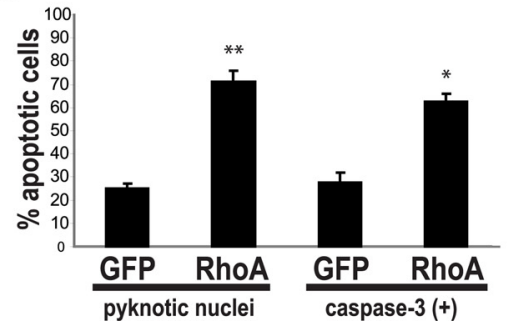

H

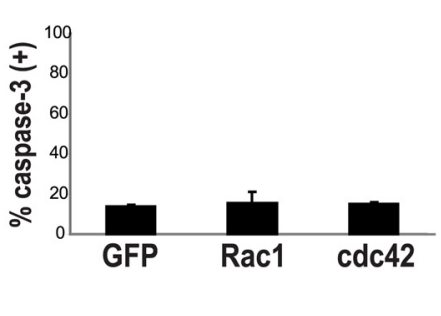

Figure 7. Apoptosis is severely reduced in somatosensory cortex of N19-RhoA mice. $\boldsymbol{A}-\boldsymbol{C}$, Immunofluorescence analysis of apoptosis in cerebral cortex of P5 wild-type $(+/+)$ and N19-RhoA/ + mice, using an antibody recognizing cleaved, activated caspase-3. For each coronal section, one telencephalic half is shown, with dorsal to the top and lateral to the right. Arrows (white) indicate positive neurons. C, Caspase-3-positive cells (green) in layers IV-VI display the typical morphology of cortical projection neurons in both wild-type $(+/+)$ and N19-RhoA/+ mice. $\boldsymbol{D}-\boldsymbol{H}$, Expression of wild-type RhoA $(\boldsymbol{D}-\boldsymbol{G}), \operatorname{Rac} 1(\boldsymbol{H}), \operatorname{orcdc} 42(\boldsymbol{H})$ in isolated cortical neurons leads to apoptosis only during expression of RhoA. Cortical neurons isolated from E16.5 embryonic cortex $48 \mathrm{~h}$ after electroporation with a GFP-tagged ( $\boldsymbol{D}$, green stain), an HA-tagged wild-type RhoA ( $\boldsymbol{E}, \boldsymbol{F}$, green stain), or a myc-tagged Rac1 $(\boldsymbol{H})$ or cdc42 $(\boldsymbol{H})$ expression construct. $\boldsymbol{D}-\boldsymbol{F}$, Red indicates staining for activated caspase-3. G, $\boldsymbol{H}$, Quantitation of GFP-, HA-, or myc-tagged positive cells for their fraction of pyknotic nuclei $(\boldsymbol{G})$ or the fraction positive for an antibody recognizing activatedcaspase-3 $(\boldsymbol{G}, \boldsymbol{H})$. In each case, $>100$ neurons were counted. ${ }^{*} p<0.05,{ }^{* *} p<0.01$, Mann-Whitney $U$ test; $n=3$. $\boldsymbol{C}-\boldsymbol{F}$, Blue indicates DAPI-labeled nuclei. Scale bars: $\boldsymbol{A}, 300 \mu \mathrm{m} ; \boldsymbol{B}, 50 \mu \mathrm{m} ; \boldsymbol{C}, \boldsymbol{F}, 10 \mu \mathrm{m} ; \boldsymbol{D}, \boldsymbol{E}, 20 \mu \mathrm{m}$.

in vivo in cerebral cortex during postnatal development. Many investigations have outlined the critical roles that components of the apoptotic machinery play in developmentally regulated cell death. For example, gene targeting of the proapoptotic protein Bax (Shindler et al., 1997), the downstream effector caspases caspase-3 (Kuida et al., 1996; Roth et al., 2000) and caspase-9 (Hakem et al., 1998; Kuida et al., 1998), and the tumor suppressor gene Pten (Groszer et al., 2001) have all shown reductions in 
levels of apoptosis and a subsequent expansion of neuronal populations. In contrast, knock-out mice for the antiapoptotic protein $\mathrm{Bcl}-\mathrm{X}_{\mathrm{L}}$ die at $\mathrm{E} 13$ with very high levels of apoptosis in the spinal cord, brainstem, and dorsal root ganglia (Motoyama et al., 1995), and deficiency in Bax has been shown to prevent the cell death in Bcl-X $\mathrm{L}_{\mathrm{L}}$ knock-out mice (Shindler et al., 1997). An epistatic pathway has been thereby delineated in which caspase-3 and caspase-9 activation lie downstream of the apoptosisactivating and -inhibiting activities of $\mathrm{Bax}$ and $\mathrm{Bcl}-\mathrm{X}_{\mathrm{L}}$, respectively (Shindler et al., 1997; Roth et al., 2000; Zaidi et al., 2001), although several other apoptosis proteins have also been shown to play a role in this process, such as Apaf1 (Cecconi et al., 1998; Yoshida et al., 1998), survivin (Jiang et al., 2005), and Pten (Groszer et al., 2001). Our results showed that inhibition of RhoA decreased the number of cleaved caspase-3-expressing neurons in cortex and that overexpression of wild-type RhoA can activate caspase-3, indicating that RhoA is involved upstream of this key executor of the apoptotic pathway. However, our results show a role of RhoA in the postnatal apoptosis in the cortex, not the embryonic apoptosis examined in the aforementioned studies. Intriguingly, RhoA has been reported to be necessary for motor neuron survival in embryonic spinal cord, using an approach very similar to the one used here (Kobayashi et al., 2004). This suggests that the role of RhoA-subfamily proteins in developmental apoptosis is very complex, because it can produce opposite effects in various neural tissues and at various developmental stages. We could not address the role of RhoA in apoptosis in embryonic cortex, because the transgene was not expressed until postnatal stages.

The exact molecular mechanism by which RhoA activity promotes apoptosis is not clear. RhoA activation was found to be necessary for both thrombin-induced (Donovan et al., 1997) and phenylalanine-induced (Zhang et al., 2007) neuronal apoptosis in vitro. The latter study identified a downstream target of activated RhoA, the Rho-activated serine/threonine kinase ROCK, as transducing the apoptotic signal from Rho, whereas p38 kinase has been shown to be activated by RhoA in excitotoxic neuronal death in the adult brain (Semenova et al., 2007). ROCK activity has clearly been shown to control the actin-myosin-based cell contractility, membrane blebbing (Coleman et al., 2001; Sebbagh et al., 2001), and nuclear disintegration (Croft et al., 2005) characteristic of apoptosis, but whether these processes are even RhoA dependent is unclear (Coleman and Olson, 2002). In any case, the in vitro studies in neurons (Donovan et al., 1997; Zhang et al., 2007) and non-neuronal cells (Jiménez et al., 1995; Lai et al., 2003; Minambres et al., 2006), together with our in vivo results, clearly place RhoA high in the pathway controlling the decision to undergo apoptosis. With respect to postnatal cortical apoptosis, very little is known of the mechanism. The overexpression of IGF-I has been shown to promote the survival of neurons in postnatal cerebral cortex (Hodge et al., 2007). It would be of great interest to see whether IGF-1 exerts its effect through modulation of Rho activity. However, knock-out studies to demonstrate a necessary role of IGF-I in this process are notably lacking. Moreover, it is entirely unclear whether the postnatal apoptotic process is ligand mediated, as in the classical case of neurotrophins and the PNS, or ligand independent. Additional studies are needed to answer this intriguing question.

Our studies show that Rho signaling is involved in apoptosis mechanism during early postnatal development. Inhibition of Rho signaling led to a cortex with a $12-26 \%$ increase in the number of neurons. Because cell death occurs over an extended prenatal and postnatal period in the neocortex, it is difficult to estimate from our counts at P5 in the cortex of the N19-RhoA expressing mice whether a $67.5 \%$ decrease in activated caspase3 -positive neurons would lead to the observed increase in excitatory neuron numbers. A previous report (Verney et al., 2000) has used terminal deoxynucleotidyl transferase-mediated biotinylated UTP nick end labeling assays to quantitatively estimate layer-specific loss of neurons during the first 2 postnatal weeks in the parietal cortex of the mouse, the same area under investigation in this study. The authors reported losses of $10-23 \%$ in this timeframe, which is in agreement with the increases in neuronal numbers that we see during inhibition of Rho-subfamily GTPases using the N19-RhoA transgene. Simple counting of total neuronal number has revealed slightly higher levels of cell death in entire postnatal mouse cortex (24-30\%) (Heumann et al., 1978). However, without detailed quantitative analyses of caspase-positive cells across different developmental ages, we cannot definitively conclude that Rho-subfamily GTPases are the sole controllers of neuronal numbers in the neocortex.

The aberrant increase in neuronal numbers occurs at the early postnatal stage in cortex, but the additional neurons persist into adulthood, which suggests that they may functionally integrate into the cortex. The supernumerary neurons are presumed to be excitatory, because a quantitation of parvalbumin-, calbindin-, and calretinin-positive interneurons indicated no change in these inhibitory populations in the N19-RhoA brain. It would be useful to see whether this increase in neuronal density results in any effects on behavior or on learning and memory. Neuronal cell loss is seen in a host of pathological conditions, including epilepsy (Henshall and Murphy, 2008), ischemia (Rami et al., 2008), microcephaly (Chen et al., 2009), alcohol abuse (Young et al., 2003), and neurodegenerative diseases such as Alzheimer's (Jellinger, 2006) and Parkinson's (Burke, 2008) disease. The protection against apoptosis seen here in early postnatal brain may be used to study neuronal loss in other contexts and potentially offers a new target for neuroprotective therapy.

\section{References}

Abercrombie M (1946) Estimation of nuclear population from microtome sections. Anat Rec 7:382-389.

Bibel M, Barde YA (2000) Neurotrophins: key regulators of cell fate and cell shape in the vertebrate nervous system. Genes Dev 14:2919-2937.

Bouzahzah B, Albanese C, Ahmed F, Pixley F, Lisanti MP, Segall JD, Condeelis J, Joyce D, Minden A, Der CJ, Chan A, Symons M, Pestell RG (2001) Rho family GTPases regulate mammary epithelium cell growth and metastasis through distinguishable pathways. Mol Med 7:816-830.

Brachmann I, Jakubick VC, Shakèd M, Unsicker K, Tucker KL (2007) A simple slice culture system for the imaging of nerve development in embryonic mouse. Dev Dyn 236:3514-3523.

Burke RE (2008) Programmed cell death and new discoveries in the genetics of parkinsonism. J Neurochem 104:875-890.

Carmona-Fontaine C, Matthews HK, Kuriyama S, Moreno M, Dunn GA, Parsons M, Stern CD, Mayor R (2008) Contact inhibition of locomotion in vivo controls neural crest directional migration. Nature 456:957-961.

Cecconi F, Alvarez-Bolado G, Meyer BI, Roth KA, Gruss P (1998) Apaf1 (CED-4 homolog) regulates programmed cell death in mammalian development. Cell 94:727-737.

Chen L, Melendez J, Campbell K, Kuan CY, Zheng Y (2009) Racl deficiency in the forebrain results in neural progenitor reduction and microcephaly. Dev Biol 325:162-170.

Chrysis D, Calikoglu AS, Ye P, D'Ercole AJ (2001) Insulin-like growth factor-I overexpression attenuates cerebellar apoptosis by altering the expression of $\mathrm{Bcl}$ family proteins in a developmentally specific manner. J Neurosci 21:1481-1489.

Coleman ML, Olson MF (2002) Rho GTPase signalling pathways in the morphological changes associated with apoptosis. Cell Death Differ 9:493-504. 
Coleman ML, Sahai EA, Yeo M, Bosch M, Dewar A, Olson MF (2001) Membrane blebbing during apoptosis results from caspase-mediated activation of ROCK I. Nat Cell Biol 3:339-345.

Croft DR, Coleman ML, Li S, Robertson D, Sullivan T, Stewart CL, Olson MF (2005) Actin-myosin-based contraction is responsible for apoptotic nuclear disintegration. J Cell Biol 168:245-255.

Donovan FM, Pike CJ, Cotman CW, Cunningham DD (1997) Thrombin induces apoptosis in cultured neurons and astrocytes via a pathway requiring tyrosine kinase and RhoA activities. J Neurosci 17:5316-5326.

Dubreuil CI, Winton MJ, McKerracher L (2003) Rho activation patterns after spinal cord injury and the role of activated Rho in apoptosis in the central nervous system. J Cell Biol 162:233-243.

Erzurumlu RS, Jhaveri S (1990) Thalamic axons confer a blueprint of the sensory periphery onto the developing rat somatosensory cortex. Brain Res Dev Brain Res 56:229-234.

Etienne-Manneville S, Hall A (2002) Rho GTPases in cell biology. Nature 420:629-635

Farnsworth CL, Feig LA (1991) Dominant inhibitory mutations in the $\mathrm{Mg}^{2+}$-binding site of RasH prevent its activation by GTP. Mol Cell Biol 11:4822-4829.

Feig LA (1994) Guanine-nucleotide exchange factors: a family of positive regulators of Ras and related GTPases. Curr Opin Cell Biol 6:204-211.

Ferrer I, Bernet E, Soriano E, del Rio T, Fonseca M (1990) Naturally occurring cell death in the cerebral cortex of the rat and removal of dead cells by transitory phagocytes. Neuroscience 39:451-458.

Ferrer I, Soriano E, del Rio JA, Alcántara S, Auladell C (1992) Cell death and removal in the cerebral cortex during development. Prog Neurobiol 39:1-43.

Finlay BL, Slattery M (1983) Local differences in the amount of early cell death in neocortex predict adult local specializations. Science 219:1349-1351.

Groszer M, Erickson R, Scripture-Adams DD, Lesche R, Trumpp A, Zack JA, Kornblum HI, Liu X, Wu H (2001) Negative regulation of neural stem/ progenitor cell proliferation by the Pten tumor suppressor gene in vivo. Science 294:2186-2189.

Groysman M, Shoval I, Kalcheim C (2008) A negative modulatory role for rho and rho-associated kinase signaling in delamination of neural crest cells. Neural Dev 3:27.

Hakem R, Hakem A, Duncan GS, Henderson JT, Woo M, Soengas MS, Elia A, de la Pompa JL, Kagi D, Khoo W, Potter J, Yoshida R, Kaufman SA, Lowe SW, Penninger JM, Mak TW (1998) Differential requirement for caspase 9 in apoptotic pathways in vivo. Cell 94:339-352.

Hall A (1998) Rho GTPases and the actin cytoskeleton. Science 279:509-514.

Hand R, Bortone D, Mattar P, Nguyen L, Heng JI, Guerrier S, Boutt E, Peters E, Barnes AP, Parras C, Schuurmans C, Guillemot F, Polleux F (2005) Phosphorylation of Neurogenin 2 specifies the migration properties and the dendritic morphology of pyramidal neurons in the neocortex. Neuron 48:45-62.

Henshall DC, Murphy BM (2008) Modulators of neuronal cell death in epilepsy. Curr Opin Pharmacol 8:75-81.

Heumann D, Leuba G (1983) Neuronal death in the development and aging of the cerebral cortex of the mouse. Neuropathol Appl Neurobiol 9:297-311.

Heumann D, Leuba G, Rabinowicz T (1978) Postnatal development of the mouse cerebral neocortex. IV. Evolution of the total cortical volume, of the population of neurons and glial cells. J Hirnforsch 19:385-393.

Hippenmeyer S, Vrieseling E, Sigrist M, Portmann T, Laengle C, Ladle DR, Arber S (2005) A developmental switch in the response of DRG neurons to ETS transcription factor signaling. PLoS Biol 3:e159.

Hodge RD, D’Ercole AJ, O'Kusky JR (2007) Insulin-like growth factor-I (IGF-I) inhibits neuronal apoptosis in the developing cerebral cortex in vivo. Int J Dev Neurosci 25:233-241.

Iwasato T, Datwani A, Wolf AM, Nishiyama H, Taguchi Y, Tonegawa S, Knöpfel T, Erzurumlu RS, Itohara S (2000) Cortex-restricted disruption of NMDAR1 impairs neuronal patterns in the barrel cortex. Nature 406:726-731.

Jellinger KA (2006) Challenges in neuronal apoptosis. Curr Alzheimer Res 3:377-391.

Jiang Y, de Bruin A, Caldas H, Fangusaro J, Hayes J, Conway EM, Robinson ML, Altura RA (2005) Essential role for survivin in early brain development. J Neurosci 25:6962-6970.
Jiménez B, Arends M, Esteve P, Perona R, Sánchez R, Ramón y Cajal S, Wyllie A, Lacal JC (1995) Induction of apoptosis in NIH3T3 cells after serum deprivation by overexpression of rho-p21, a GTPase protein of the ras superfamily. Oncogene 10:811-816.

Katoh H, Aoki J, Ichikawa A, Negishi M (1998) p160 RhoA-binding kinase ROKalpha induces neurite retraction. J Biol Chem 273:2489-2492.

Kobayashi K, Takahashi M, Matsushita N, Miyazaki J, Koike M, Yaginuma H, Osumi N, Kaibuchi K, Kobayashi K (2004) Survival of developing motor neurons mediated by Rho GTPase signaling pathway through Rhokinase. J Neurosci 24:3480-3488.

Kuan CY, Roth KA, Flavell RA, Rakic P (2000) Mechanisms of programmed cell death in the developing brain. Trends Neurosci 23:291-297.

Kuida K, Zheng TS, Na S, Kuan C, Yang D, Karasuyama H, Rakic P, Flavell RA (1996) Decreased apoptosis in the brain and premature lethality in CPP32-deficient mice. Nature 384:368-372.

Kuida K, Haydar TF, Kuan CY, Gu Y, Taya C, Karasuyama H, Su MS, Rakic P, Flavell RA (1998) Reduced apoptosis and cytochrome c-mediated caspase activation in mice lacking caspase 9. Cell 94:325-337.

Lai JM, Hsieh CL, Chang ZF (2003) Caspase activation during phorbol ester-induced apoptosis requires ROCK-dependent myosin-mediated contraction. J Cell Sci 116:3491-3501.

Lakso M, Pichel JG, Gorman JR, Sauer B, Okamoto Y, Lee E, Alt FW, Westphal H (1996) Efficient in vivo manipulation of mouse genomic sequences at the zygote stage. Proc Natl Acad Sci U S A 93:5860-5865.

Lebrand C, Cases O, Wehrlé R, Blakely RD, Edwards RH, Gaspar P (1998) Transient developmental expression of monoamine transporters in the rodent forebrain. J Comp Neurol 401:506-524.

Liu JP, Jessell TM (1998) A role for rhoB in the delamination of neural crest cells from the dorsal neural tube. Development 125:5055-5067.

Luo L (2000) Rho GTPases in neuronal morphogenesis. Nat Rev Neurosci 1:173-180.

Lyck L, Krøigård T, Finsen B (2007) Unbiased cell quantification reveals a continued increase in the number of neocortical neurones during early post-natal development in mice. Eur J Neurosci 26:1749-1764.

Markram H, Toledo-Rodriguez M, Wang Y, Gupta A, Silberberg G, Wu C (2004) Interneurons of the neocortical inhibitory system. Nat Rev Neurosci 5:793-807.

Miñambres R, Guasch RM, Perez-Aragó A, Guerri C (2006) The RhoA/ ROCK-I/MLC pathway is involved in the ethanol-induced apoptosis by anoikis in astrocytes. J Cell Sci 119:271-282.

Motoyama N, Wang F, Roth KA, Sawa H, Nakayama K, Nakayama K, Negishi I, Senju S, Zhang Q, Fujii S, et al (1995) Massive cell death of immature hematopoietic cells and neurons in Bcl-x-deficient mice. Science 267:1506-1510.

Mullen RJ, Buck CR, Smith AM (1992) NeuN, a neuronal specific nuclear protein in vertebrates. Development 116:201-211.

Pearlman AL (1985) The visual cortex of the normal mouse and the reeler mutant. In: Cerebral cortex, Vol 3, Visual cortex (Peters A, Jones EG, eds), pp 1-18. New York: Plenum.

Porter AG, Jänicke RU (1999) Emerging roles of caspase-3 in apoptosis. Cell Death Differ 6:99-104.

Price DJ, Blakemore C (1985) Regressive events in the postnatal development of association projections in the visual cortex. Nature 316:721-724.

Purves D (1990) Body and brain: a trophic theory of neural connections. Cambridge, MA: Harvard UP.

Qiu RG, Chen J, McCormick F, Symons M (1995) A role for Rho in Ras transformation. Proc Natl Acad Sci U S A 92:11781-11785.

Rami A, Bechmann I, Stehle JH (2008) Exploiting endogenous antiapoptotic proteins for novel therapeutic strategies in cerebral ischemia. Prog Neurobiol 85:273-296.

Rebsam A, Seif I, Gaspar P (2002) Refinement of thalamocortical arbors and emergence of barrel domains in the primary somatosensory cortex: a study of normal and monoamine oxidase a knock-out mice. J Neurosci 22:8541-8552.

Ren XD, Kiosses WB, Schwartz MA (1999) Regulation of the small GTPbinding protein Rho by cell adhesion and the cytoskeleton. EMBO J 18:578-585.

Rossman KL, Der CJ, Sondek J (2005) GEF means go: turning on RHO GTPases with guanine nucleotide-exchange factors. Nat Rev Mol Cell Biol 6:167-180.

Roth KA, Kuan C, Haydar TF, D’Sa-Eipper C, Shindler KS, Zheng TS, Kuida K, Flavell RA, Rakic P (2000) Epistatic and independent functions of 
caspase- 3 and Bcl-X(L) in developmental programmed cell death. Proc Natl Acad Sci U S A 97:466-471.

Rupp PA, Kulesa PM (2007) A role for RhoA in the two-phase migratory pattern of post-otic neural crest cells. Dev Biol 311:159-171.

Sebbagh M, Renvoizé C, Hamelin J, Riché N, Bertoglio J, Bréard J (2001) Caspase-3-mediated cleavage of ROCK I induces MLC phosphorylation and apoptotic membrane blebbing. Nat Cell Biol 3:346-352.

Semenova MM, Mäki-Hokkonen AM, Cao J, Komarovski V, Forsberg KM, Koistinaho M, Coffey ET, Courtney MJ (2007) Rho mediates calciumdependent activation of p38alpha and subsequent excitotoxic cell death. Nat Neurosci 10:436-443.

Senft SL, Woolsey TA (1991) Growth of thalamic afferents into mouse barrel cortex. Cereb Cortex 1:308-335.

Shakèd M, Weissmüller K, Svoboda H, Hortschansky P, Nishino N, Wölfl S, Tucker KL (2008) Histone deacetylases control neurogenesis in embryonic brain by inhibition of BMP2/4 signaling. PLoS ONE 3:e2668.

Shindler KS, Latham CB, Roth KA (1997) Bax deficiency prevents the increased cell death of immature neurons in bcl-x-deficient mice. J Neurosci 17:3112-3119.

Spreafico R, Frassoni C, Arcelli P, Selvaggio M, De Biasi S (1995) In situ labeling of apoptotic cell death in the cerebral cortex and thalamus of rats during development. J Comp Neurol 363:281-295.

Tucker KL, Meyer M, Barde YA (2001) Neurotrophins are required for nerve growth during development. Nat Neurosci 4:29-37.

Verney C, Takahashi T, Bhide PG, Nowakowski RS, Caviness VS Jr (2000)
Independent controls for neocortical neuron production and histogenetic cell death. Dev Neurosci 22:125-138.

Willaredt MA, Hasenpusch-Theil K, Gardner HA, Kitanovic I, HirschfeldWarneken VC, Gojak CP, Gorgas K, Bradford CL, Spatz J, Wölfl S, Theil T, Tucker KL (2008) A crucial role for primary cilia in cortical morphogenesis. J Neurosci 28:12887-12900.

Wójciak-Stothard B, Williams L, Ridley AJ (1999) Monocyte adhesion and spreading on human endothelial cells is dependent on Rho-regulated receptor clustering. J Cell Biol 145:1293-1307.

Woolsey TA, Van der Loos H (1970) The structural organization of layer IV in the somatosensory region (SI) of mouse cerebral cortex. The description of a cortical field composed of discrete cytoarchitectonic units. Brain Res 17:205-242.

Yoshida H, Kong YY, Yoshida R, Elia AJ, Hakem A, Hakem R, Penninger JM, Mak TW (1998) Apaf1 is required for mitochondrial pathways of apoptosis and brain development. Cell 94:739-750.

Young C, Klocke BJ, Tenkova T, Choi J, Labruyere J, Qin YQ, Holtzman DM, Roth KA, Olney JW (2003) Ethanol-induced neuronal apoptosis in vivo requires BAX in the developing mouse brain. Cell Death Differ 10:1148-1155.

Zaidi AU, D'Sa-Eipper C, Brenner J, Kuida K, Zheng TS, Flavell RA, Rakic P, Roth KA (2001) Bcl-X(L)-caspase-9 interactions in the developing nervous system: evidence for multiple death pathways. J Neurosci 21:169-175.

Zhang Y, Gu X, Yuan X (2007) Phenylalanine activates the mitochondriamediated apoptosis through the RhoA/Rho-associated kinase pathway in cortical neurons. Eur J Neurosci 25:1341-1348. 